\title{
Modelling Impacts of Climate Change on Maize (Zea mays L.) Growth and Productivity: A Review of Models, Outputs and Limitations
}

\author{
Benjamin Kipkemboi Kogo ${ }^{1 *}$, Lalit Kumar'1, Richard Koech², Philip Langat ${ }^{1}$ \\ ${ }^{1}$ School of Environmental and Rural Science, University of New England, Armidale, Australia \\ ${ }^{2}$ School of Health, Medical and Applied Sciences, Central Queensland University, Bundaberg, Australia \\ Email: ^bkogo@myune.edu.au
}

How to cite this paper: Kogo, B. K., Kumar, L., Koech, R., \& Langat, P. (2019). Modelling Impacts of Climate Change on Maize (Zea mays L.) Growth and Productivity: A Review of Models, Outputs and Limitations. Journal of Geoscience and Environment Protection, 7, 76-95.

https://doi.org/10.4236/gep.2019.78006

Received: June 28, 2019

Accepted: August 10, 2019

Published: August 13, 2019

Copyright $\odot 2019$ by author(s) and Scientific Research Publishing Inc. This work is licensed under the Creative Commons Attribution International License (CC BY 4.0).

http://creativecommons.org/licenses/by/4.0/

(c) $\underset{\mathrm{EY}}{\mathrm{C}}$ Open Access

\begin{abstract}
The use of crop modelling in various cropping systems and environments to project and upscale agronomic decision-making under the facets of climate change has gained currency in recent years. This paper provides an evaluation of crop models that have been used by researchers to simulate maize growth and productivity. Through a systematic review approach, a comprehensive assessment of 186 published articles was carried out to establish the models and parameterization features, simulated impacts on maize yields and adaptation strategies in the last three decades. Of the 23 models identified, CERES-maize and APSIM models were the most dominant, representing $49.7 \%$ of the studies undertaken between 1990 and 2018. Current research shows projected decline in maize yields of between $8 \%-38 \%$ under RCP4.5 and RCP 8.5 scenarios by the end of the $21^{\text {st }}$ century, and that adaptation is essential in alleviating the impacts of climate change. Major agro-adaptation options considered in most papers are changes in planting dates, cultivars and crop water management practices. The use of multiple crop models and multi-model ensembles from general circulation models (GCMs) is recommended. As interest in crop modelling grows, future work should focus more on suitability of agricultural lands for maize production under climate scenarios.
\end{abstract}

\section{Keywords}

Crop Modelling, Climate Scenarios, Maize, Simulation, GCM

\section{Introduction}

There is an increasing recognition that climate change has led to intra-seasonal 
yield variability and may also alter crop production in the $21^{\text {st }}$ century (Basso, Cammarano, \& Carfagna, 2013; Deb, Shrestha, \& Babel, 2015; FAO, 2009). The most significant aspect of climate change is severity and occurrence of extreme weather events such as floods, drought and heat stress (Bassu et al., 2014; IPCC, 2007; Stocker et al., 2013). Other factors that affect growth and productivity of crops include the crop agronomic management such as water application, tillage, fertilizer application and seasonal changes in the magnitude and trend of temperature, precipitation and solar radiation (Ahmed et al., 2018; Kang, Khan, \& $\mathrm{Ma}, 2009)$. The Intergovernmental Panel on Climate Change Special Report on Emissions Scenarios (IPCC, 2018) projected the possibility of regional differences in global production with the possibility of affecting over 5 million people who are likely to be at risk of hunger by 2100 (Stocker et al., 2013). According to IPCC (2018), the projected increase in global warming to $1.5^{\circ} \mathrm{C}$ is likely to reduce productivity of key cereals including maize, rice and wheat in sub-Saharan Africa, Southeast Asia, and Central and South America.

In order to ensure today's food security and in the coming decades, efforts have been made on establishment of crop simulation models aimed at predicting growth, development and yield potential of a crop under certain environmental conditions (Basso et al., 2013; Wang et al., 2018; Xiao \& Tao, 2016). Several dynamic crop simulations models (CSMs) have been developed and used widely to study physiological, physical and chemical processes of crop productivity under a changing climate (Kasampalis et al., 2018; Shi, Tao, \& Zhang, 2013; White, Hoogenboom, Kimball, \& Wall, 2011). The crop models and their outputs are then used to guide agronomic decision-making aimed at sustainable management and development of adaptive strategies for responding to impacts of climate change (Basso et al., 2013). Optimum management practices that are either strategic or tactful including planting dates, selection of crop variety, fertilizer usage and water application can be analysed through proven models for planning purposes (Boote, Jones, \& Pickering, 1996). Furthermore, crop simulation models can play a major role in evaluating the potential impacts of climate change on agricultural systems in the world (IPCC, 2007; Stocker et al., 2013). Likewise, CSMs have played a key role in interpretation of agronomic results and are increasingly being used by farmers and policy-makers for decision-making in crop production. The differences in spatio-temporal scales and predicted changes in global climate and land use have led to development of several crop models by researchers for agronomic purposes. In addition, several general circulation models (GCMs) have also been developed for use in crop modelling and other related aspects (IPCC, 2007). Thus, the crop-modelling subject has attracted many researchers and policy makers and was one of the major issues discussed during the COP21 agreement in Paris in 2015.

Scientific research on climate and crop modelling in the last three decades has increased tremendously and it is of critical importance to have an overview of existing models and their use, including their outputs, to inform future investigations. Such an assessment can help answer weighty questions such as: 1) What 
models are being used in crop simulation? 2) What are the input data and processes simulated? 3) Where have these models been applied? and 4) What are the outputs and limitations. Previous work undertaken have mainly focused on impacts of climate change on crop production in certain regions, some on generalised crop models and others on certain features of crop modelling. For example, Zinyengere et al. (2011) examined the impacts of climate change in South Africa with the main focus being adaptation and carbon dioxide fertilization. Webber, Gaiser, and Ewert (2014) reviewed the role and suitability of crop models in aiding adaptation decisions towards food security in sub-Saharan Africa. Boote et al. (1996) discussed the uses and limitations of crop models. In this study, we review papers published in journals for the past 28 years (from 1990 to 2018) with the main objective of exploring the models that are specifically used to simulate the impact of climate change on maize growth and productivity. This review forms a beneficial reference by addressing the limitations that exist on identification of the available models, the parameterization requirements, and the regions where such models have been applied. In the paper, we consider maize (Zea mays L.) since it is a major crop grown in most parts of the world to provide food and nutritional security for the vulnerable populations (Tesfaye et al., 2015). Like other crops, the main challenge that affects maize growth and development is the changing weather pattern, leading to intra-seasonal changes in yield (Lin et al., 2017). Other factors are variable soil properties, crop agronomic management practices including planting, fertilizer application, tillage among others (Ahmed et al., 2018; Lin et al., 2017; Ramirez-Cabral, Kumar, \& Shabani, 2017; Tesfaye et al., 2015; Tesfaye et al., 2018). We believe that analysing the performance of various maize simulation models is vital for addressing the challenges posed by climate change.

The specific objectives of the review include: 1) identification of the various models and geographic locations used, including the input parameters and simulated processes; 2) examination of the projected simulated yields from various models and the adaptation measures applied; and 3) identification of limitations and future perspectives in crop modelling. This paper is intended to provide a basis for researchers as well as agronomic decision-makers who are interested in understanding the available maize simulation models and devising suitable perspectives in crop modelling.

This paper is organized as follows: Section 2 describes the methodology used in the identification of peer-reviewed articles of interest. The results are presented in Section 3 focusing on the models available and their features, summary of articles published in the review period and overview on model objectives. In Section 4, a detailed discussion of the models and an overview of simulated impacts of climate change on maize are presented. Lastly, Section 5 is on conclusion and recommendations.

\section{Methodology}

Our study adopted a systematic review process as described in the scheme of 
Figure 1. We used ISI Web of Knowledge (IWK) as the main source for identification of relevant peer reviewed articles. IWK was selected because it is one of the oldest citation databases with wide coverage of high impact journals that are mostly written in English (Aghaei Chadegani et al., 2013; Levine-Clark \& Gil, 2008). The first inclusion criteria involved searching of articles with the title maize and topics that included climate change, model, yield and simulation. The second inclusion criteria limited results to journal articles that were specific to maize and climate change on their titles. Lastly, the list of papers was filtered to exclude articles whose objectives were not focused on maize production, the non-peer reviewed journal articles, those written in languages other than English and those not available through internet sources. With an addition of five more papers that were identified through cross-referencing, the ultimate sources of literature for this study were 186 papers dating from 1990 to 2018. An excel spreadsheet was developed to enter specific information on location of the study areas, model used, objective of the study, input parameters and outputs. Schematic representation of the systematic review process is presented in Figure 1.

Following the screening process, the other steps were extraction of information from the articles according to the following thematic areas:

- The simulation model used in the study

- Focus of the model, input data and processes simulated

- General circulation model (GCM) applied

- Geographic location of the study

- Objectives of the research, simulated outputs and adaptation strategies

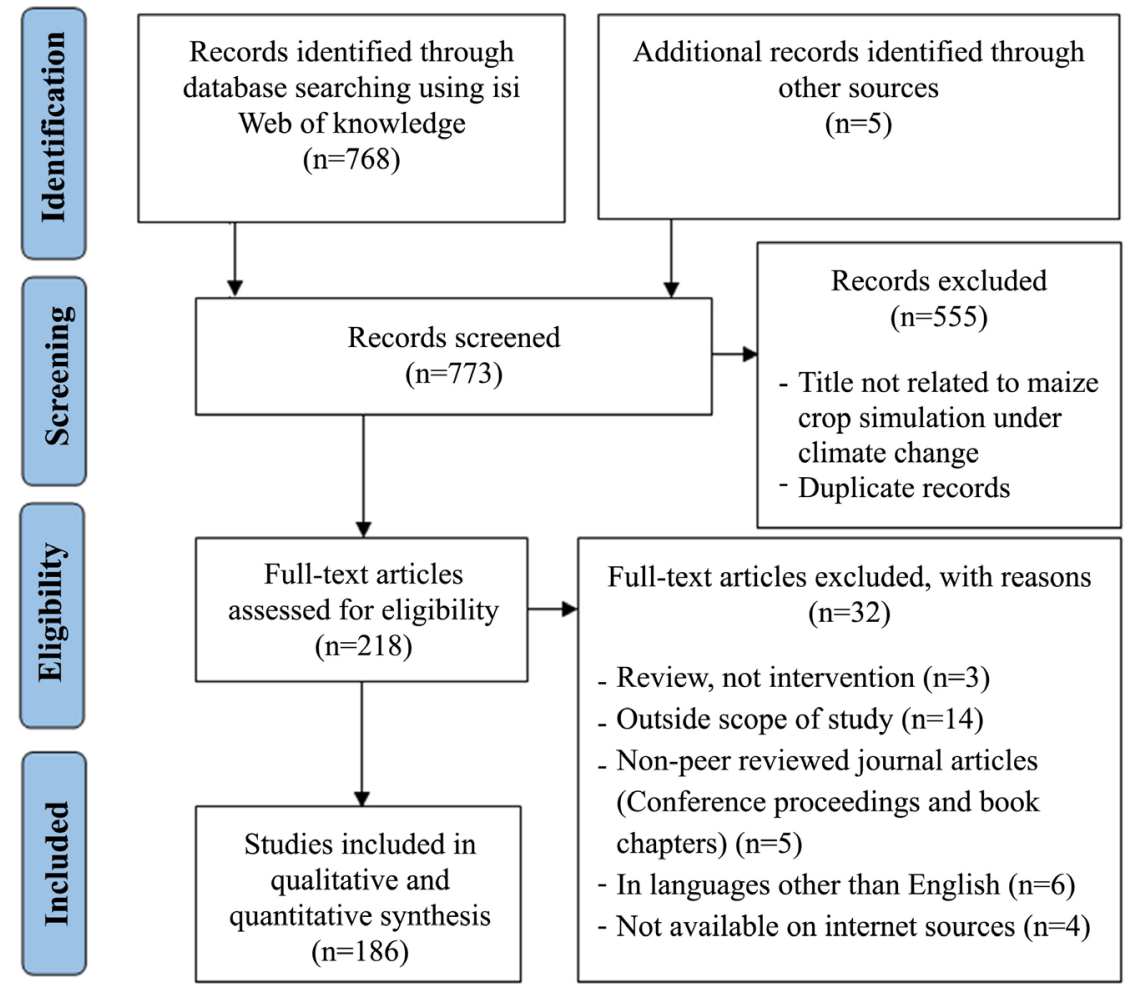

Figure 1. Flowchart detailing the systematic review process. 


\section{Results}

\subsection{Maize Simulation Models}

Based on the criteria we used in our assessment, we identified 23 models that have been developed to simulate the impacts of climate change on maize production (Table 1). The dominant models identified were CERES Maize (59 articles) and APSIM (30 articles).

\subsection{Publications and Geographic Locations of the Studies}

The counts of journal articles published within the review period (1990 to 2018) has increased significantly (Figure 2); the highest number being recorded in 2015 and none in 2005. The highest number of studies on maize yield simulation under the impacts of climate change has been undertaken in Asia, and the least in Australia, of all countries where models have been applied. The geographic distribution of the models in the various continents is presented in Figure 3.

\subsection{Focus of the Model, Input Data and Processes Simulated}

In terms of the selected features, the 21 models mainly focused on simulation of maize growth and yields, with the exception of CLIMEX and MaxEnt models whose focus was on predicting geographic distribution of maize under climate change scenarios. The GCMs that dominated in most articles were ECHAM5, CCSM, HadCM3, CSIRO-MK3, CGCM3.1, UKLO and MIROC3.2. The input parameters that were established to be common in most models were: 1) weather data including temperature, daily rainfall and solar radiation; 2) soil data including soil type, soil depth, soil texture, soil organic carbon, bulk density, soil nitrogen; 3) crop information and management of crop species, planting date, row space, plant density; 4) field management practices such as water management, irrigation usage including scheduling, method and amount applied, fertilizer

Table 1. Models used to simulate maize production under climate change.

\begin{tabular}{cccccc}
\hline Model & No. of Articles & Model & No. of Articles & Model & No. of Articles \\
\hline CERES-Maize & 59 & CROPWAT & 2 & SPACSYS & 1 \\
APSIM & 30 & ISAREG & 2 & FASSET & 1 \\
statistical & 12 & MAISPROQ & 2 & SICTOD & 1 \\
Cropyst & 10 & MaxEnt & 2 & LINTUL5 & 1 \\
WOFOST & 9 & 4 M crop & 1 & WINISAREG & 1 \\
AquaCrop & 8 & Agro-IBIS & 1 & GAEZ & 1 \\
DSSAT & 8 & AgroMetShell & 1 & MCWLA & 1 \\
InfoCrop & 8 & AirMS & 1 & SuperEPPS & 1 \\
EPIC & 4 & ARMOSA & 1 & SIMETAW & 1 \\
GLAM & 3 & BISM & 1 & CLIMEX & 1 \\
CMSM & 3 & WHCNS & 1 & &
\end{tabular}




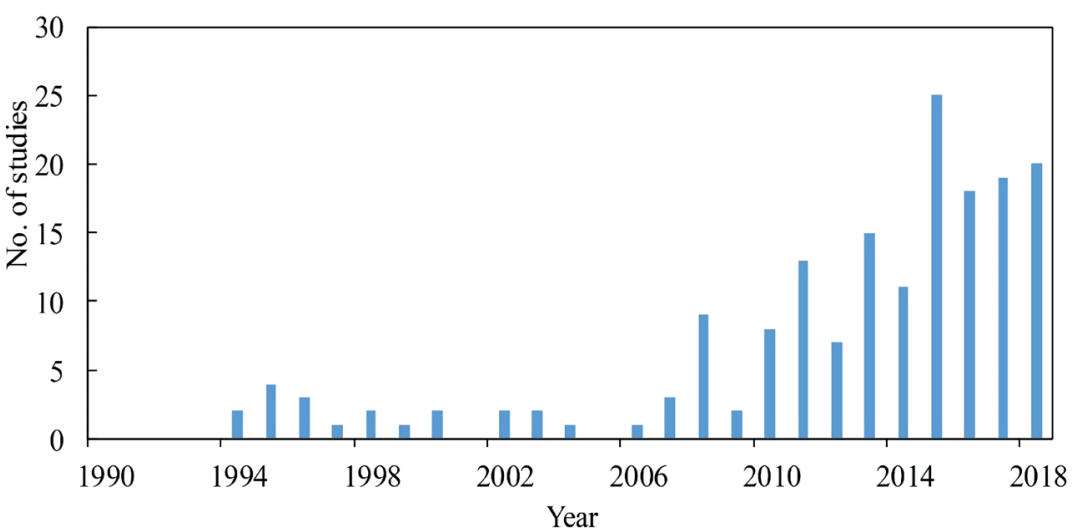

Figure 2. Absolute number of published papers on maize simulation models (extracted from ISI Web of Knowledge).

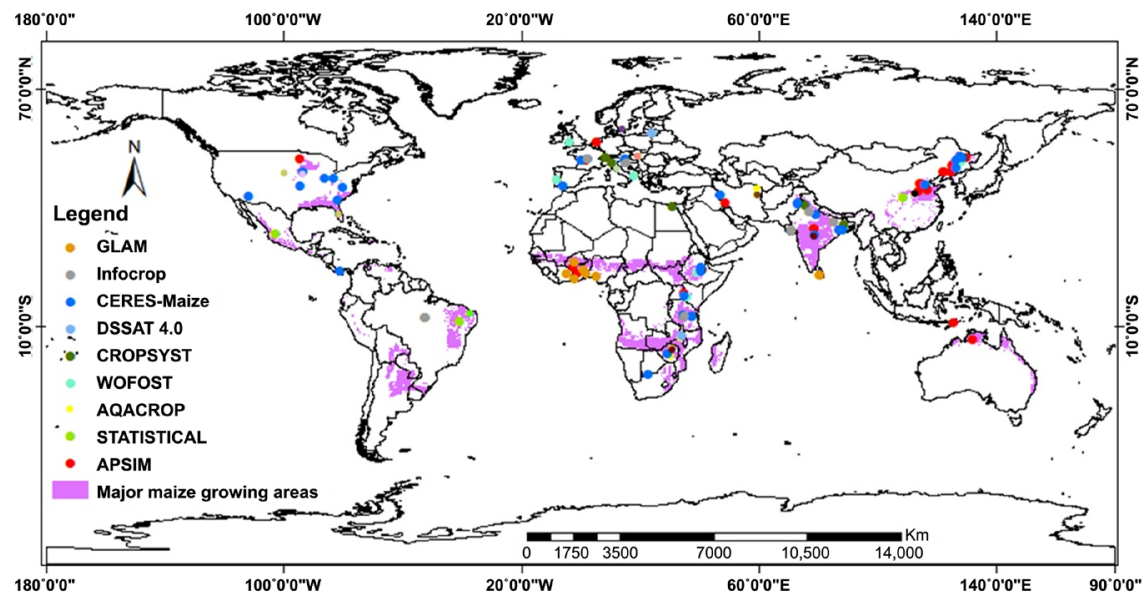

Figure 3. Distribution of the major maize simulation models in the world. The major maize growing areas shown in the figure was extracted from http://www.fao.org/geonetwork, accessed on $2^{\text {nd }}$ March 2019.

usage and type, pesticide application and tillage practices. The physiological process simulated by most models are phenology, biomass and evapotranspiration. Specific input parameters for the models and processes simulated are presented in Table 2.

\subsection{Objectives of the Papers}

The objectives presented in different papers ranged from analysing the maize yields under the impacts of climate change, to adaptation strategies and model suitability (Table 3). From the findings, most (46.6\%) of the papers investigated the impacts of climate change on maize production in terms of yields.

\section{Discussion and Synthesis}

\subsection{Model Evaluation}

From the assessment, a total of 23 different simulation models were identified from the articles (Table 1). Of these, CERES-maize and APSIM models were the 
Table 2. Detailed evaluation of the models.

\begin{tabular}{|c|c|c|c|c|}
\hline Model & Focus of model & Input parameters for model & Physiological process simulated & Sample References \\
\hline $\begin{array}{l}\text { Crop-Environment } \\
\text { Resource Synthesis } \\
\text { (CERES)-Maize }\end{array}$ & $\begin{array}{l}\text { Simulate growth and } \\
\text { yield }\end{array}$ & $\begin{array}{l}\text { Weather, crop, soil } \\
\text { and management }\end{array}$ & $\begin{array}{l}\text { Phenology, photoperiod, biomass, } \\
\text { canopy development, water and nitrogen } \\
\text { dynamics }\end{array}$ & $\begin{array}{l}\text { (Araya et al., 2015; } \\
\text { Araya et al., 2017) }\end{array}$ \\
\hline $\begin{array}{l}\text { Agricultural Production } \\
\text { Systems Simulator } \\
\text { (APSIM) }\end{array}$ & $\begin{array}{l}\text { Simulate growth and } \\
\text { yield }\end{array}$ & $\begin{array}{l}\text { Temperature, soil, } \\
\text { precipitation and } \\
\text { solarradiation }\end{array}$ & $\begin{array}{l}\text { Phenology, biomass, canopy, root } \\
\text { system, senescence pools, water, nitrogen } \\
\text { and phosphorus }\end{array}$ & $\begin{array}{l}\text { (Araya et al., 2015; Kim, } \\
\text { Myoung, Stack, Kim, \& } \\
\text { Kafatos, 2016; Xiao et } \\
\text { al., 2016) }\end{array}$ \\
\hline $\begin{array}{l}\text { Statistical crop yield } \\
\text { model }\end{array}$ & Yield estimation & $\begin{array}{l}\text { Radiation, water deficit, } \\
\text { average temperature, frost, } \\
\text { and heat stress. }\end{array}$ & $\begin{array}{l}\text { Simulate growth, development and yield, } \\
\text { the soil and plant water, nitrogen and } \\
\text { carbon Balances }\end{array}$ & $\begin{array}{c}\text { (Landman, Engelbrecht, } \\
\text { Hewitson, Malherbe, \& } \\
\text { van der Merwe, 2018) }\end{array}$ \\
\hline $\begin{array}{l}\text { Cropping Systems } \\
\text { Simulation Model } \\
\text { (CropSyst) }\end{array}$ & $\begin{array}{l}\text { Simulate growth and } \\
\text { yield }\end{array}$ & $\begin{array}{l}\text { Daily weather, soil profile } \\
\text { properties and crop } \\
\text { management }\end{array}$ & Daily biomass accumulation & $\begin{array}{c}\text { (Abraha \& Savage, } \\
\text { 2006; Tingem, } \\
\text { Rivington, \& Colls, 2008) }\end{array}$ \\
\hline $\begin{array}{l}\text { World Food Studies } \\
\text { (WOFOST) crop model }\end{array}$ & $\begin{array}{l}\text { Simulate growth and } \\
\text { yield }\end{array}$ & $\begin{array}{l}\text { Weather data, soil data, crop } \\
\text { management data }\end{array}$ & $\begin{array}{l}\text { Light interception, photosynthesis } \\
\text { and respiration, evapotranspiration, leaf } \\
\text { area dynamics, phonology and root } \\
\text { growth }\end{array}$ & $\begin{array}{c}\text { (Ceglar \& } \\
\text { Kajfez-Bogataj, 2012; } \\
\text { Ogutu, Franssen, Supit, } \\
\text { Omondi, \& Hutjes, } \\
\text { 2018) }\end{array}$ \\
\hline AquaCrop & Yield estimation & $\begin{array}{l}\text { Weather, crop and } \\
\text { characteristics, management } \\
\text { practices }\end{array}$ & $\begin{array}{l}\text { Effect of water stress on crop } \\
\text { development, crop transpiration ground } \\
\text { biomass and yield and water uptake }\end{array}$ & $\begin{array}{l}\text { (Zydelis, Weihermuller, } \\
\text { Herbst, Klosterhalfen, } \\
\text { \& Lazauskas, 2018) }\end{array}$ \\
\hline $\begin{array}{l}\text { Decision Support System } \\
\text { for Agro-technology } \\
\text { Transfer (DSSAT) }\end{array}$ & Yield estimation & $\begin{array}{l}\text { Weather, soil data and crop } \\
\text { management data. }\end{array}$ & $\begin{array}{l}\text { Growth, development and yield, the soil } \\
\text { and plant water, nitrogen and carbon } \\
\text { balances }\end{array}$ & $\begin{array}{l}\text { (Ngwira, Aune, \& } \\
\text { Thierfelder, 2014) }\end{array}$ \\
\hline InfoCrop & Yield estimation & $\begin{array}{l}\text { Weather, cultivar, agronomic } \\
\text { inputs, soil data }\end{array}$ & $\begin{array}{l}\text { Crop and development, effects of water, } \\
\text { nitrogen, temperature, crop-pest } \\
\text { interactions, soil water balance }\end{array}$ & $\begin{array}{c}\text { (Choudhary, Patel, } \\
\text { Yadav, \& Pandey, 2014) }\end{array}$ \\
\hline $\begin{array}{l}\text { Environmental Policy } \\
\text { Integrated Climate model } \\
\text { (EPIC) }\end{array}$ & Yield estimation & $\begin{array}{l}\text { Topography, land cover, } \\
\text { weather, soil, management, } \\
\text { and plant parameters }\end{array}$ & $\begin{array}{l}\text { Biomass to energy ratio, the harvest } \\
\text { index, planting density, photosynthetic } \\
\text { active radiation, radiation use efficiency } \\
\text { factor, and vapor pressure deficit }\end{array}$ & (Xiong et al., 2016) \\
\hline $\begin{array}{l}\text { General Large Area } \\
\text { Model (GLAM) }\end{array}$ & Yield estimation & $\begin{array}{l}\text { Weather, crop parameters, } \\
\text { soil properties, management } \\
\text { practices }\end{array}$ & $\begin{array}{l}\text { Biomass, harvest index, nutrient } \\
\text { deficiency }\end{array}$ & $\begin{array}{l}\text { (Waongo, Laux, \& } \\
\text { Kunstmann, 2015) }\end{array}$ \\
\hline CROPWAT & $\begin{array}{l}\text { Determine crop } \\
\text { water requirements }\end{array}$ & $\begin{array}{l}\text { Temperature, wind speed, } \\
\text { sun-shine hours, relative } \\
\text { humidity and rainfall }\end{array}$ & Crop water requirements & (Diossy, 2008) \\
\hline $\begin{array}{l}\text { Maximum Entropy } \\
\text { (MaxEnt) model }\end{array}$ & $\begin{array}{l}\text { Geographical } \\
\text { distribution and } \\
\text { climate suitability of } \\
\text { species }\end{array}$ & $\begin{array}{l}\text { Bioclimatic variables including } \\
\text { annual precipitation, annual } \\
\text { temperature }\end{array}$ & Habitat suitability & $\begin{array}{l}\text { (Nabout, Caetano, } \\
\text { Ferreira, Teixeira, \& } \\
\text { Alves, 2012) }\end{array}$ \\
\hline $4 \mathrm{M}$ crop & Yield estimation & $\begin{array}{l}\text { Solar radiation, temperature } \\
\text { and precipitation }\end{array}$ & $\begin{array}{l}\text { Development and growth } \\
\text { of plants and the heat, water and nutrient } \\
\text { balance of the soil }\end{array}$ & (Fogarasi et al., 2016) \\
\hline $\begin{array}{l}\text { Agro-Integrated } \\
\text { Biosphere Simulator } \\
\text { (Agro-IBIS) }\end{array}$ & Yield estimation & $\begin{array}{l}\text { solar radiation, temperature, } \\
\text { precipitation, humidity, wind } \\
\text { speed, and soil properties }\end{array}$ & $\begin{array}{l}\text { Leaf growth, and soil carbon storage and } \\
\text { turnover }\end{array}$ & $\begin{array}{l}\text { (Xu, Twine, \& } \\
\text { Girvetz, 2016) }\end{array}$ \\
\hline AgroMetShell & Yield simulation & $\begin{array}{l}\text { Precipitation, potential } \\
\text { evapotranspiration }\end{array}$ & $\begin{array}{l}\text { total water requirement, excess soil } \\
\text { water, soil water deficit and water } \\
\text { satisfaction index }\end{array}$ & $\begin{array}{l}\text { (Crespo, Hachigonta, \& } \\
\text { Tadross, 2011) }\end{array}$ \\
\hline
\end{tabular}




\begin{tabular}{|c|c|c|c|c|}
\hline ARMOSA & Yield estimates & $\begin{array}{l}\text { Weather, soil physical and } \\
\text { chemical properties, crop and } \\
\text { soil related variables (e.g. crop } \\
\text { yield, crop nitrogen uptake, } \\
\text { soil water content) }\end{array}$ & $\begin{array}{l}\text { the root elongation rate and maximum } \\
\text { depth, stomatal resistance and actual } \\
\text { transpiration estimation, and drought } \\
\text { tolerance factor }\end{array}$ & (Perego et al., 2014) \\
\hline $\begin{array}{l}\text { Water Heat Carbon } \\
\text { Nitrogen Simulator } \\
\text { (WHCNS) }\end{array}$ & Yield potential & $\begin{array}{l}\text { precipitation, temperature, } \\
\text { humidity, solar radiation }\end{array}$ & $\begin{array}{l}\text { soil water movement, soil heat and } \mathrm{N} \\
\text { transport, and crop growth }\end{array}$ & $\begin{array}{l}\text { (He, Liang, Hu, Wang, } \\
\quad \text { \& Hou, 2018) }\end{array}$ \\
\hline $\begin{array}{l}\text { Soil-Plant-Atmosphere } \\
\text { Continuum System } \\
\text { (SPACSYS) }\end{array}$ & Yield potential & $\begin{array}{l}\text { Weather, } \mathrm{CO}_{2} \text {, precipitation, } \\
\text { crop management, soil } \\
\text { properties }\end{array}$ & $\begin{array}{l}\text { Plant growth and development, root } \\
\text { system and processes associated with soil } \\
\mathrm{C} \text { and N cycle }\end{array}$ & (Liang et al., 2018) \\
\hline $\begin{array}{l}\text { Farm Assessment Tool } \\
\text { (FASSET) }\end{array}$ & Yield potential & $\begin{array}{l}\text { Temperature, precipitation, } \\
\text { soil data, Crop management }\end{array}$ & $\begin{array}{l}\text { crop growth dry matter production and } \\
\mathrm{N} \text { content of vegetative, storage and root } \\
\text { organs }\end{array}$ & $\begin{array}{l}\text { (Ozturk, Kristensen, \& } \\
\text { Baby, 2018) }\end{array}$ \\
\hline $\begin{array}{l}\text { Global Agro-Ecological } \\
\text { Zones (GAEZ) model }\end{array}$ & Yield potential & $\begin{array}{l}\text { solar radiation, air } \\
\text { temperature, and crop } \\
\text { characteristics }\end{array}$ & Crop growth & $\begin{array}{l}\text { (Xu, Wang, Sun, Liu, \& } \\
\text { Banson, 2017) }\end{array}$ \\
\hline $\begin{array}{l}\text { Crop-Weather } \\
\text { relationship over a Large } \\
\text { Area (MCWLA) }\end{array}$ & $\begin{array}{l}\text { Adaptation of maize } \\
\text { production }\end{array}$ & $\begin{array}{l}\text { crop growth and } \\
\text { development, canopy } \\
\text { development, flowering, and } \\
\text { maturity }\end{array}$ & $\begin{array}{l}\text { Mean temperature, precipitation, vapour } \\
\text { pressure, and fractional sunshine hours. }\end{array}$ & (Tao \& Zhang, 2010) \\
\hline $\begin{array}{l}\text { Simulation of } \\
\text { evapotranspiration of } \\
\text { applied water } \\
\text { (SIMETAW) model }\end{array}$ & Yield estimates & $\begin{array}{l}\text { Maximum, minimum, and } \\
\text { dew point temperature, } \\
\text { precipitation, wind speed and } \\
\text { soil data }\end{array}$ & effective rooting depths and ETc & $\begin{array}{l}\text { (Yang, Gao, Shi, Chen, } \\
\quad \& \text { Chu, 2013) }\end{array}$ \\
\hline CLIMEX & $\begin{array}{l}\text { Geographical } \\
\text { distribution and } \\
\text { climate suitability of } \\
\text { species }\end{array}$ & $\begin{array}{l}\text { Temperature, average } \\
\text { precipitation, relative humid- } \\
\text { ity, soil moisture data }\end{array}$ & Crop phenology and stress indices & $\begin{array}{l}\text { (Ramirez-Cabral et al., } \\
\text { 2017) }\end{array}$ \\
\hline
\end{tabular}

Table 3. Objectives of the selected crop modelling papers published between 1990 and 2018.

\begin{tabular}{cc}
\hline Objective of the paper & No. of papers (\%) \\
\hline Adaptation & 25.2 \\
Impact on maize yields & 46.6 \\
Impacts and adaptation & 23.8 \\
Model suitability, impact and adaptation & 1.9 \\
Model suitability & 2.4 \\
\hline
\end{tabular}

most dominant, representing $49.7 \%$ of the models. The models identified were majorly process-based that have been developed to compute crop dynamics based on deterministic equations and simulation of underlying processes at particular time scales (Roberts, Braun, Sinclair, Lobell, \& Schlenker, 2017). To give an insight into the distribution of the studies, the geographic locations were dominated by Asia (35\% of the articles) and Europe (26\% of the articles) that researched on impacts of climate change on maize production. In particular, North China and France were the major areas where several studies have been 
undertaken. Fewer studies were observed in Brazil, and East and South Africa, which are among the major maize producers in the world. This observation is an indicator of the limitation in the developing countries (especially Africa) where minimal studies have been undertaken, despite the challenge of climate change and the lack of adequate adaptation strategies to sustainably manage crop production (IPCC, 2014). The major uncertainties in undertaking studies in these countries could be associated with inadequate information, lack of continuous long-term crop data and facilities that can play a great role in defining research priorities on crop modelling with an aim of understanding plant responses to the changing environment (Di Paola, Valentini, \& Santini, 2016). As a result of this, there is inadequate information that can be passed to stakeholders and farmers due to minimal research, lack of access and uncertainties associated with data used (Whitfield, 2013). Therefore, it is imperative that governments in developing countries or regions with limited data prioritise collection of weather data and support more research on modelling in order to plan strategies for adapting to the impacts of climate change on crop productivity.

Of the 186 articles, only $7.5 \%$ simulated maize growth with more than one crop model. Those that simulated results with more than one GCM were approximately $17.2 \%$. This then points to a possibility of uncertainties in results obtained from several studies using single crop models and GCMs. In line with this, Zhang, Zhao, and Feng (2018) in their study, observed that GCMs contributed more uncertainties to maize-yield simulations compared to crop simulation models that use observed environmental data. Therefore, the use of more than one model is encouraged in analysing the impact of climate change on crops in order to compare results which may vary due to the structure and model parameters (Shi et al., 2013; Tao, Zhang, Liu, \& Yokozawa, 2009). In line with this, Semenov and Stratonovitch (2010), Bassu et al. (2014) and Zhang et al. (2018) noted that the use of multiple crop models is imperative in accounting for uncertainties in simulated results from individual predictions. Shi et al. (2013) recommended the combination of crop and statistical models in order to achieve better results on response of crop yields to climate change.

\subsection{Impacts of Climate Change on Maize Productivity}

Most reviewed articles (81\%) assessed the impacts of climate change on maize productivity. Others were on yield, biomass and leaf area index (14\%), biomass (5\%) and area suitability for maize production (1\%). Based on this review, the variability in simulated maize yield under the climate change scenarios RCP4.5 and RCP8.5 in several studies showed decreases in maize yield of between $8 \%$ to $38 \%$. A typical example is the finding of Haris, Biswas, Chhabra, Elanchezhian, and Bhatt (2013) and Ceglar and Kajfez-Bogataj (2012) on their study using WOFOST model in Central Europe that showed a decrease in maize yield of between $10 \%$ and $16 \%$ in the 2050 s and between $27 \%$ and $34 \%$ in the 2090 s under HadCM3 and ECHAM5 scenario. Similarly, Lin et al. (2017), using CERES 
maize in several sites in Northern China showed that the average maize yield would decrease by $2.1 \%$ in 2020 s, $12.9 \%$ in 2050 s and $22.7 \%$ in 2080 s under RCP4.5. Moreover, they projected greater reduction of $6.3 \%, 18.4 \%$ and $47.5 \%$ in the respective periods under RCP 8.5 without considering the effects of $\mathrm{CO}_{2}$ fertilization. Again, a study conducted by Choudhary et al. (2014) using InfoCrop model in India projected an increase of both maximum and minimum temperature by $4.3^{\circ} \mathrm{C}$ and $\mathrm{CO}_{2}$ concentration by $0.24 \mathrm{ppm}$ on annual basis between 2071 and 2100 leading to reduction of total biomass by approximately $10 \%$ and LAI by $16 \%$. In West Africa, Parkes, Sultan, and Ciais (2018), in their study using General Large Area Model (GLAM), projected a reduction of maize yields by $5.95 \%$ with an increase of temperature. A study by Araya et al. (2015) in Ethiopia using APSIM and CERES maize models under 20 GCMs and RCP 4.5 and 8.5 reported an increase in maize yields of between $1.7 \%$ and $4.2 \%$. Araya et al. (2017) using multiple GCMs in western Kansas reported a decline of maize yield in the mid- $21^{\text {st }}$ century by $18 \%-33 \%$ under RCP 4.5 and $37 \%-46 \%$ under RCP 8.5. A study by H. Xu et al. (2016) in IOWA using Agri-IBIS model established that maize yields are projected to decreased by $10 \%-20 \%$ by end of the $21^{\text {st }}$ century even with sufficient amount of water and in the strongest climate forcing scenario.

Studies that considered the effect of carbon dioxide fertilization in the years 2050 and 2070 reported that maize, being a C4 plant, is likely to decrease in yields, especially under increased water stress conditions. For example, Lin et al. (2017) forecasted a reduction of maize yield due to $\mathrm{CO}_{2}$ fertilization from 22.7 to $19.5 \%$ under RCP4.5 and $47.5 \%$ to $44.1 \%$ under RCP 8.5. Z. Jin et al. (2017) reported a mean decrease in yields of maize in the USA by $12 \%$ and $25 \%$ under RCP 4.5 and RCP 8.5 respectively, which are comparable to other studies that use multiple-process-based models under multiple GCMs (Ruane et al., 2013).

In terms of area suitability for maize production, Ramirez-Cabral et al. (2017) in their study using CLIMEX distribution model with climate data CSIRO-Mk3.0 and MIROC-H GCMs predicted high loss of climate suitability for maize production between the tropics of Cancer and Capricorn (highest being in South America, followed by Africa and Oceania); whereas poleward regions (including Asia, Europe and North America) exhibit increase in suitability.

In analysing the outputs of the simulated results from the models, one of the challenges in this review was to undertake an inter-comparison of the estimated yields, which in most cases differed in various studies. This is supported by the works of Bassu et al. (2014) who pointed out that different models produce different projected impacts of climate change due to variability in parameterization processes. In addition, model simulations vary due to differences in structure, processes considered and their relative importance depending on the region where the model was developed (Challinor, Ewert, Arnold, Simelton, \& Fraser, 2009). For instance, the parameters that influence crop yield could be different from those of temporal changes in various regions, therefore confirming the lack 
of a modelling methodology that can perform equally well across the globe (Hansen \& Jones, 2000; Reidsma, Ewert, Boogaard, \& van Diepen, 2009).

In general, most studies and models reviewed reported mainly on maize production and yields compared to those that analysed variation in geographic suitability and distribution of the crop as influenced by climate change.

\subsection{Adaptation Strategies and Their Implications}

While estimates using different maize simulation models project decline in yields, most studies emphasized that future maize production can benefit from various adaptation strategies aimed at offsetting the negative impacts of climate change on maize production. Some of the dominant adaptation measures considered in 44 studies shown in Table 3 (25 on adaptation and 19 on impact and adaptation) were change of sowing date, cultivars and crop water management, respectively represented by $47 \%, 31 \%$ and $3 \%$ of the studies under this review. The major adaptation strategies suggested for consideration on crop models include breeding new cultivars, proper irrigation and soil nutrient management (Bannayan, Paymard, \& Ashraf, 2016; Lin et al., 2017; Moradi, Koocheki, Mahallati, \& Mansoori, 2013; Rurinda et al., 2015; Xiao \& Tao, 2016).

The study by Lana et al. (2016) is a notable example that reported how change of planting date impacted on maize yields. In their works, by using CERES-Maize model without factoring in adaptation strategies, showed reduction of $11.5 \%$ $13.5 \%$ in total maize production across the cultivars used. They also reported that by combining cultivar and the best planting date, they simulated an increase in production by $15 \%$. Similarly, a study in Northern China by Lin et al. (2017) showed that maize yields would decrease by $6.9 \%$ and increase by $15.9 \%$ if planting days were advanced or delayed by 15 days respectively. Another notable example is by Parent et al. (2018) who, in their study using APSIM model and six field experiments in South and Northern Europe projected an increase of $4 \%$ - 7\% in grain production through adaptation that involves genetic variability of flowering during the crop cycle. Rahimi-Moghaddam, Kambouzia, and Deihimfard (2018) found that, by combining early sowing and using cultivars which have high thermal time requirements in North Eastern, there is high likelihood of reducing the impact of climate change on maize productivity. Lashkari, Alizadeh, Rezaei, and Bannayan (2012), Bannayan et al. (2016) and (Araya et al., 2015; Araya et al., 2017; Reddy et al., 2016) in their studies also reported positive effects of early sowing dates as an adaptive strategy towards impact of climate change. D. P. Xiao et al. (2016) in their study in North China Plain using APSIM model concluded that cultivation of maize cultivars with longer growing periods and higher thermal requirements could be a potential adaptation measure towards mitigating the impacts of climate change on crop production.

Adequate polices on adapting agriculture to climate change have also been proposed. For example, Kang et al. (2009) in their study on climate variability and droughts in Australia proposed adjustments in allocation of surface and 
ground water, improvements in water use efficiencies in agriculture and establishment of a legal framework towards management of water resources in line with anticipated impacts of climate change on water resources. Approaches such as these can be used to ensure integrated water resources management and allocations that can also benefit crop production through irrigation.

\subsection{Limitations of Crop Modelling}

The limitations inherent in crop models include the input parameters, calibration, evaluation and validation procedures and methods of simulating crop responses to various environmental and management factors, leading to uncertainties in prediction of crop yields and identification of appropriate measures towards adaptation (Bassu et al., 2014; Moradi et al., 2013). Likewise, as the intended objectives of various models differ, the structure of the model including the input parameters may result in differences in projected climatic impacts, which in most cases are based on estimations. The performance of models is also constrained by the accuracy and precision of the input data, which can be affected by poor calibration of the sensors used in the research study before model applications (Boote et al., 1996). For example, most researchers use "above-ground" crop data as compared to data related to root growth and development which are not extensive and with enormous sampling errors. In addition, very few studies accounted for important factors which play an important role in crop development, such as weeds, diseases, insects, cultivation and phosphorous. According to Basso et al. (2013), one of the challenges in crop modelling is the use of observed and simulated results to determine the cause of spatial and temporal crop variability and how to manage the crop from agronomic, environmental and economic perspectives. Other limitations associated with crop models are related to sensitivity to $\mathrm{CO}_{2}$, which has major influence on projected changes and remains an obstacle to the assessment of the impacts of climate change (Ruane et al., 2013).

The use of GCMs provides reasonable accuracy on wide-scale assessments. However, their use for the prediction of climate scenarios is not without limitations (Kang et al., 2009; Whitfield, 2013). These include systematic errors such as the tendency of northward displacement during winter in the northern hemisphere, too wet simulations in the middle latitudes of both hemispheres and underestimation of clouds in the tropics (D'andrea \& Vautard, 2000). Therefore, the use of GCMs with higher spatial resolutions is recommended in order to acquire realistic projections on the impacts of climate change on crop production at a regional scale (Reddy \& Hodges, 2000).

Due to problems associated with field variabilities and challenges in the acquisition of data, integration of remote sensing and crop modelling is important for in-season crop management (Moulin, Bondeau, \& Delecolle, 1998). Under this approach, crop simulation models can offer a good understanding of temporal variability of crops and remote sensing images can be used to acquire informa- 
tion on actual variability and spatial distribution of crops during the growing season (Basso et al., 2013; Bastiaanssen, Molden, \& Makin, 2000; Bayode, 2014; Kalian \& Spannraft, 2010). This direction is supported by several experiments undertaken to monitor crop development in the field which have shown that remote sensing measurements in different wavelengths can provide information on crop activity and environmental conditions without undertaking actual field data collection. For instance, the major integration between remote sensing and crop simulation model is on adjusting the leaf area index (LAI) to model crop evapotranspiration, accumulation of biomass and estimation of yields (Dorigo et al., 2007; Jin et al., 2018; Jin et al., 2016; Strachan, Stewart, \& Pattey, 2005). Though Basso et al. (2013) argued that remote sensing may not be suitable for use in mixed agricultural lands and small farm sizes, especially in developing countries where available satellite data is not of good quality, the future of crop modelling is more expected to integrate remote sensing.

\section{Conclusion and Future Work}

This paper presents the crops models that are used to simulate maize growth and development. Through a systematic review of literature, we identified 23 simulation models from ISI Web of Knowledge that have been used to research and simulate maize productivity under the impact of climate variability. For the last two decades, these models have played a significant role in research, farm-level management and agronomic decision-making. To emphasize our findings, the following points briefly summarize our review and the future perspectives drawn:

- Most articles have focused on projecting impact of climate change on maize production compared to adaptation and suitability of the geographic area for maize production. It is clear that with the anticipated effects of climate change, adaptation of maize production systems is essential.

- The process-based models that are used in maize simulation vary in their complexity but share some inter-comparable input parameters and plant processes that include phenology, canopy and biomass establishment. Comparability of the input parameters in the models is relevant for climate change studies where results can inform decision-making and policy direction.

- With the broadening of crop simulation models, concerns include the reliability of outcomes from a single simulation model that may not adequately factor in all the pertinent processes. To address this challenge, the use of multiple crop models and GCMs to simulate crop growth remains a major consideration in future crop modelling in order to minimize uncertainties in simulated results that can be linked with individual predictions.

- Integration of remote sensing and crop models presents feasible agronomic consideration for monitoring of crop growth and yield forecasting.

- As interest in crop modelling continues to grow, future research should focus 
on modelling the spatial and temporal variability and suitability of agricultural lands for maize production, which is currently under-researched.

Though there could be some research gap regarding the criteria used in this systematic review and in analysing the large amount of diverse peer-reviewed articles, the results of this study provide not only important insights on the diversified maize simulation models and projected outputs, but also provide better understanding of the projected impacts, adaptations and future works towards sustainable maize production under the adverse impacts of climate change.

\section{Conflicts of Interest}

The authors declare no conflicts of interest regarding the publication of this paper.

\section{References}

Abraha, M. G., \& Savage, M. J. (2006). Potential Impacts of Climate Change on the Grain Yield of Maize for the Midlands of KwaZulu-Natal, South Africa. Agriculture Ecosystems \& Environment, 115, 150-160. https://doi.org/10.1016/j.agee.2005.12.020

Aghaei Chadegani, A., Salehi, H., Yunus, M., Farhadi, H., Fooladi, M., Farhadi, M., \& Ale Ebrahim, N. (2013). A Comparison between Two Main Academic Literature Collections: Web of Science and Scopus Databases. Asian Social Science, 9, 18-26.

https://doi.org/10.5539/ass.v9n5p18

Ahmed, I., Ur Rahman, M. H., Ahmed, S., Hussain, J., Ullah, A., \& Judge, J. (2018). Assessing the Impact of Climate Variability on Maize Using Simulation Modeling under Semi-Arid Environment of Punjab, Pakistan. Environmental Science and Pollution Research, 25, 28413-28430. https://doi.org/10.1007/s11356-018-2884-3

Araya, A., Hoogenboom, G., Luedeling, E., Hadgu, K. M., Kisekka, I., \& Martorano, L. G. (2015). Assessment of Maize Growth and Yield Using Crop Models under Present and Future Climate in Southwestern Ethiopia. Agricultural and Forest Meteorology, 214, 252-265. https://doi.org/10.1016/j.agrformet.2015.08.259

Araya, A., Kisekka, I., Lin, X., Prasad, P. V. V., Gowda, P. H., Rice, C., \& Andales, A. (2017). Evaluating the Impact of Future Climate Change on Irrigated Maize Production in Kansas. Climate Risk Management, 17, 139-154.

https://doi.org/10.1016/j.crm.2017.08.001

Bannayan, M., Paymard, P., \& Ashraf, B. (2016). Vulnerability of Maize Production under Future Climate Change: Possible Adaptation Strategies. Journal of the Science of Food and Agriculture, 96, 4465-4474. https://doi.org/10.1002/jsfa.7659

Basso, B., Cammarano, D., \& Carfagna, E. (2013). Review of Crop Yield Forecasting Methods and Early Warning Systems. In Proceedings of the First Meeting of the Scientific Advisory Committee of the Global Strategy to Improve Agricultural and Rural Statistics (pp. 15-31). Rome: FAO Headquarters.

Bassu, S., Brisson, N., Durand, J. L., Boote, K., Lizaso, J., Jones, J. W., Baron, C. et al. (2014). How Do Various Maize Crop Models Vary in Their Responses to Climate Change Factors? Global Change Biology, 20, 2301-2320. https://doi.org/10.1111/gcb.12520

Bastiaanssen, W. G., Molden, D. J., \& Makin, I. W. (2000). Remote Sensing for Irrigated Agriculture: Examples from Research and Possible Applications. Agricultural Water Management, 46, 137-155. https://doi.org/10.1016/S0378-3774(00)00080-9 
Bayode, N. (2014). Climate Change Analysis and Adaptation: The Role of Remote Sensing (Rs) and Geographical Information System (Gis).

Boote, K. J., Jones, J. W., \& Pickering, N. B. (1996). Potential Uses and Limitations of Crop Models. Agronomy Journal, 88, 704-716. https://doi.org/10.2134/agronj1996.00021962008800050005x

Ceglar, A., \& Kajfez-Bogataj, L. (2012). Simulation of Maize Yield in Current and Changed Climatic Conditions: Addressing Modelling Uncertainties and the Importance of Bias Correction in Climate Model Simulations. European Journal of Agrono$m y$, 37, 83-95. https://doi.org/10.1016/j.eja.2011.11.005

Challinor, A. J., Ewert, F., Arnold, S., Simelton, E., \& Fraser, E. (2009). Crops and Climate Change: Progress, Trends, and Challenges in Simulating Impacts and Informing Adaptation. Journal of Experimental Botany, 60, 2775-2789.

https://doi.org/10.1093/jxb/erp062

Choudhary, D., Patel, H. R., Yadav, S. B., \& Pandey, V. (2014). Assessment of Climate Change under A2 Scenario and Its Effect on Rabi Maize (Zea mays L.) Yield Using InfoCrop Model for Dahod District of Middle Gujarat Agro Climatic Zone. Annals of Biology, 30, 509-514.

Crespo, O., Hachigonta, S., \& Tadross, M. (2011). Sensitivity of Southern African Maize Yields to the Definition of Sowing Dekad in a Changing Climate. Climatic Change, 106, 267-283. https://doi.org/10.1007/s10584-010-9924-4

D’andrea, F., \& Vautard, R. (2000). Reducing Systematic Errors by Empirically Correcting Model Errors. Tellus A, 52, 21-41. https://doi.org/10.1034/j.1600-0870.2000.520103.x

Deb, P., Shrestha, S., \& Babel, M. S. (2015). Forecasting Climate Change Impacts and Evaluation of Adaptation Options for Maize Cropping in the Hilly Terrain of Himalayas: Sikkim, India. Theoretical and Applied Climatology, 121, 649-667. https://doi.org/10.1007/s00704-014-1262-4

Di Paola, A., Valentini, R., \& Santini, M. (2016). An Overview of Available Crop Growth and Yield Models for Studies and Assessments in Agriculture. Journal of the Science of Food and Agriculture, 96, 709-714. https://doi.org/10.1002/jsfa.7359

Diossy, L. (2008). The Influence of Global Climate Change on Air and Soil Temperatures in Maize Canopy. Idojaras, 112, 125-139.

Dorigo, W. A., Zurita-Milla, R., de Wit, A. J., Brazile, J., Singh, R., \& Schaepman, M. E. (2007). A Review on Reflective Remote Sensing and Data Assimilation Techniques for Enhanced Agroecosystem Modeling. International Journal of Applied Earth Observation and Geoinformation, 9, 165-193. https://doi.org/10.1016/j.jag.2006.05.003

FAO (2009). Declaration of the World Summit on Food Security. In World Summit on Food Security (pp. 1-7). Rome: FAO.

Fogarasi, J., Kemeny, G., Molnar, A., Kemenyne Horvath, Z., Zubor-Nemes, A., \& Kiss, A. (2016). Modelling Climate Effects on Hungarian Winter Wheat and Maize Yields. Studies in Agricultural Economics, 118, 85-90. https://doi.org/10.7896/j.1614

Hansen, J., \& Jones, J. (2000). Scaling-Up Crop Models for Climate Variability Applications. Agricultural Systems, 65, 43-72. https://doi.org/10.1016/S0308-521X(00)00025-1

Haris, A. V. A., Biswas, S., Chhabra, V., Elanchezhian, R., \& Bhatt, B. P. (2013). Impact of Climate Change on Wheat and Winter Maize over a Sub-Humid Climatic Environment. Current Science, 104, 206-214. https://doi.org/10.1007/s40003-013-0079-1

He, Y., Liang, H., Hu, K. L., Wang, H. Y., \& Hou, L. L. (2018). Modeling Nitrogen Leaching in a Spring Maize System under Changing Climate and Genotype Scenarios in Arid Inner Mongolia, China. Agricultural Water Management, 210, 316-323. 
https://doi.org/10.1016/j.agwat.2018.08.017

IPCC (2007). Climate Change 2007: Impacts, Adaptation and Vulnerability. Report of the Working Group II to the Fourth Assessment Report of the IPCC.

IPCC (2014). Climate Change 2014: Impacts, Adaptation, and Vulnerability. Part B: Regional Aspects. In V. R. Barros, C. B. Field, D. J. Dokken, M. D. Mastrandrea, K. J. Mach, T. E. Bilir, M. Chatterjee, K. L. Ebi, Y. O. Estrada, R. C. Genova, B. Girma, E. S. Kissel, A. N. Levy, S. MacCracken, P. R. Mastrandrea, \& L. L. White (Eds.), Contribution of Working Group II to the Fifth Assessment Report of the Intergovernmental Panel on Climate Change (p. 688). Geneva: IPCC.

IPCC (2018). Summary for Policymakers. In V. Masson-Delmotte, P. Zhai, H.-O. Pörtner, D. Roberts, J. Skea, P. R. Shukla, A. Pirani, W. Moufouma-Okia, C. Péan, R. Pidcock, S. Connors, J. B. R. Matthews, Y. Chen, X. Zhou, M. I. Gomis, E. Lonnoy, T. Maycock, M. Tignor, \& T. Waterfield (Eds.), Global Warming of $1.5^{\circ} \mathrm{C}$. An IPCC Special Report on the Impacts of Global Warming of $1.5{ }^{\circ} \mathrm{C}$ above Pre-Industrial Levels and Related Global Greenhouse Gas Emission Pathways, in the Context of Strengthening the Global Response to the Threat of Climate Change, Sustainable Development, and Efforts to Eradicate Poverty (32 p.). Geneva: World Meteorological Organization.

Jin, X., Kumar, L., Li, Z., Feng, H., Xu, X., Yang, G., \& Wang, J. (2018). A Review of Data Assimilation of Remote Sensing and Crop Models. European Journal of Agronomy, 92, 141-152. https://doi.org/10.1016/j.eja.2017.11.002

Jin, X., Kumar, L., Li, Z., Xu, X., Yang, G., \& Wang, J. (2016). Estimation of Winter Wheat Biomass and Yield by Combining the AquaCrop Model and Field Hyperspectral Data. Remote Sensing, 8, 972. https://doi.org/10.3390/rs8120972

Jin, Z., Zhuang, Q. L., Wang, J. L., Archontoulis, S. V., Zobel, Z., \& Kotamarthi, V. R. (2017). The Combined and Separate Impacts of Climate Extremes on the Current and Future US Rainfed Maize and Soybean Production under Elevated $\mathrm{CO}_{2}$. Global Change Biology, 23, 2687-2704. https://doi.org/10.1111/gcb.13617

Kalian, K., \& Spannraft, K. (2010). Remote Sensing and Climate Change. GeoInformatics, $13,20$.

Kang, Y., Khan, S., \& Ma, X. (2009). Climate Change Impacts on Crop Yield, Crop Water Productivity and Food Security-A Review. Progress in Natural Science, 19, 1665-1674. https://doi.org/10.1016/j.pnsc.2009.08.001

Kasampalis, D., Alexandridis, T., Deva, C., Challinor, A., Moshou, D., \& Zalidis, G. (2018). Contribution of Remote Sensing on Crop Models: A Review. Journal of Imaging, 4, 52. https://doi.org/10.3390/jimaging4040052

Kim, S. H., Myoung, B., Stack, D. H., Kim, J., \& Kafatos, M. C. (2016). Sensitivity of Maize Yield Potential to Regional Climate in the Southwestern US. Transactions of the $A S A B E$, 59, 1745-1757. https://doi.org/10.13031/trans.59.11584

Lana, M. A., Eulenstein, F., Schlindwein, S., Guevara, E., Meira, S., Wurbs, A., Bonatti, M. et al. (2016). Regionalization of Climate Scenarios Impacts on Maize Production and the Role of Cultivar and Planting Date as an Adaptation Strategy. Regional Environmental Change, 16, 1319-1331. https://doi.org/10.1007/s10113-015-0860-8

Landman, W. A., Engelbrecht, F., Hewitson, B., Malherbe, J., \& van der Merwe, J. (2018). Towards Bridging the Gap between Climate Change Projections and Maize Producers in South Africa. Theoretical and Applied Climatology, 132, 1153-1163.

https://doi.org/10.1007/s00704-017-2168-8

Lashkari, A., Alizadeh, A., Rezaei, E. E., \& Bannayan, M. (2012). Mitigation of Climate Change Impacts on Maize Productivity in Northeast of Iran: A Simulation Study. Mitigation and Adaptation Strategies for Global Change, 17, 1-16. 
https://doi.org/10.1007/s11027-011-9305-y

Levine-Clark, M., \& Gil, E. L. (2008). A Comparative Citation Analysis of Web of Science, Scopus, and Google Scholar. Journal of Business \& Finance Librarianship, 14, 32-46. https://doi.org/10.1080/08963560802176348

Liang, S., Li, Y. F., Zhang, X. B., Sun, Z. G., Sun, N., Duan, Y. H., Wu, L. H. et al. (2018). Response of Crop Yield and Nitrogen Use Efficiency for Wheat-Maize Cropping System to Future Climate Change in Northern China. Agricultural and Forest Meteorology, 262, 310-321. https://doi.org/10.1016/j.agrformet.2018.07.019

Lin, Y., Feng, Z., Wu, W., Yang, Y., Zhou, Y., \& Xu, C. (2017). Potential Impacts of Climate Change and Adaptation on Maize in Northeast China. Agronomy Journal, 109, 1476-1490. https://doi.org/10.2134/agronj2016.05.0275

Moradi, R., Koocheki, A., Mahallati, M. N., \& Mansoori, H. (2013). Adaptation Strategies for Maize Cultivation under Climate Change in Iran: Irrigation and Planting Date Management. Mitigation and Adaptation Strategies for Global Change, 18, 265-284. https://doi.org/10.1007/s11027-012-9410-6

Moulin, S., Bondeau, A., \& Delecolle, R. (1998). Combining Agricultural Crop Models and Satellite Observations: From Field to Regional Scales. International Journal of Remote Sensing, 19, 1021-1036. https://doi.org/10.1080/014311698215586

Nabout, J. C., Caetano, J. M., Ferreira, R. B., Teixeira, I. R., \& Alves, S. M. D. (2012). Using Correlative, Mechanistic and Hybrid Niche Models to Predict the Productivity and Impact of Global Climate Change on Maize Crop in Brazil. Natureza \& Conservacao, 10, 177-183. https://doi.org/10.4322/natcon.2012.034

Ngwira, A. R., Aune, J. B., \& Thierfelder, C. (2014). DSSAT Modelling of Conservation Agriculture Maize Response to Climate Change in Malawi. Soil \& Tillage Research, 143, 85-94. https://doi.org/10.1016/j.still.2014.05.003

Ogutu, G. E. O., Franssen, W. H. P., Supit, I., Omondi, P., \& Hutjes, R. W. A. (2018). Probabilistic Maize Yield Prediction over East Africa Using Dynamic Ensemble Seasonal Climate Forecasts. Agricultural and Forest Meteorology, 250, 243-261. https://doi.org/10.1016/j.agrformet.2017.12.256

Ozturk, I., Kristensen, I. S., \& Baby, S. (2018). Sensitivity of Silage-Maize to Climate Change in Denmark: A Productivity Analysis Using Impact Response Surface. European Journal of Agronomy, 98, 55-64. https://doi.org/10.1016/j.eja.2018.05.007

Parent, B., Leclere, M., Lacube, S., Semenov, M. A., Welcker, C., Martre, P., \& Tardieu, F. (2018). Maize Yields over Europe May Increase in Spite of Climate Change, with an Appropriate Use of the Genetic Variability of Flowering Time. Proceedings of the National Academy of Sciences of the United States of America, 115, 10642-10647. https://doi.org/10.1073/pnas.1720716115

Parkes, B., Sultan, B., \& Ciais, P. (2018). The Impact of Future Climate Change and Potential Adaptation Methods on Maize Yields in West Africa. Climatic Change, 151, 205-217. https://doi.org/10.1007/s10584-018-2290-3

Perego, A., Sanna, M., Giussani, A., Chiodini, M. E., Fumagalli, M., Pilu, S. R., Acutis, M. et al. (2014). Designing a High-Yielding Maize Ideotype for a Changing Climate in Lombardy Plain (Northern Italy). Science of the Total Environment, 499, 497-509. https://doi.org/10.1016/j.scitotenv.2014.05.092

Rahimi-Moghaddam, S., Kambouzia, J., \& Deihimfard, R. (2018). Adaptation Strategies to Lessen Negative Impact of Climate Change on Grain Maize under Hot Climatic Conditions: A Model-Based Assessment. Agricultural and Forest Meteorology, 253, 1-14. https://doi.org/10.1016/j.agrformet.2018.01.032 
Ramirez-Cabral, N. Y., Kumar, L., \& Shabani, F. (2017). Global Alterations in Areas of Suitability for Maize Production from Climate Change and Using a Mechanistic Species Distribution Model (CLIMEX). Scientific Reports, 7, Article No. 5910. https://doi.org/10.1038/s41598-017-05804-0

Reddy, K., Kumar, M., Maruthi, V., Lakshminarayana, P., Vijayalakshmi, B., \& Reddy, Y. (2016). Climate Change Impacts on Crop Water Balance of Maize (Zea mays L.) in Lower Krishna River Basin of South India. Current Science, 111, 565.

https://doi.org/10.18520/cs/v111/i3/565-570

Reddy, K. R., \& Hodges, H. (2000). Climate Change and Global Crop Productivity. Wallingford: CABI. https://doi.org/10.1079/9780851994390.0007

Reidsma, P., Ewert, F., Boogaard, H., \& van Diepen, K. (2009). Regional Crop Modelling in Europe: The Impact of Climatic Conditions and Farm Characteristics on Maize Yields. Agricultural Systems, 100, 51-60. https://doi.org/10.1016/j.agsy.2008.12.009

Roberts, M. J., Braun, N. O., Sinclair, T. R., Lobell, D. B., \& Schlenker, W. (2017). Comparing and Combining Process-Based Crop Models and Statistical Models with Some Implications for Climate Change. Environmental Research Letters, 12, Article ID: 095010. https://doi.org/10.1088/1748-9326/aa7f33

Ruane, A. C., Cecil, L. D., Horton, R. M., Gordon, R., McCollum, R., Brown, D., Rosenzweig, C. et al. (2013). Climate Change Impact Uncertainties for Maize in Panama: Farm Information, Climate Projections, and Yield Sensitivities. Agricultural and Forest Meteorology, 170, 132-145. https://doi.org/10.1016/j.agrformet.2011.10.015

Rurinda, J., Van Wijk, M. T., Mapfumo, P., Descheemaeker, K., Supit, I., \& Giller, K. E. (2015). Climate Change and Maize Yield in Southern Africa: What Can Farm Management Do? Global Change Biology, 21, 4588-4601. https://doi.org/10.1111/gcb.13061

Semenov, M. A., \& Stratonovitch, P. (2010). Use of Multi-Model Ensembles from Global Climate Models for Assessment of Climate Change Impacts. Climate Research, 41, 1-14. https://doi.org/10.3354/cr00836

Shi, W., Tao, F., \& Zhang, Z. (2013). A Review on Statistical Models for Identifying Climate Contributions to Crop Yields. Journal of Geographical Sciences, 23, 567-576. https://doi.org/10.1007/s11442-013-1029-3

Stocker, T., Qin, D., Plattner, G., Tignor, M., Allen, S., Boschung, J., Midgley, P. et al. (2013). IPCC, 2013: Summary for Policymakers in Climate Change 2013: The Physical Science Basis, Contribution of Working Group I to the Fifth Assessment Report of the Intergovernmental Panel on Climate Change. Cambridge: Cambridge University Press.

Strachan, I., Stewart, D., \& Pattey, E. (2005). Determination of Leaf Area Index in Agricultural Systems. In J. L. Hatfield, \& J. M. Baker (Eds.), Micrometeorology in Agricultural Systems (pp. 179-198). Monograph 47, Madison, WI: ASA, CSSA, SSSA.

Tao, F., Zhang, Z., Liu, J., \& Yokozawa, M. (2009). Modelling the Impacts of Weather and Climate Variability on Crop Productivity over a Large Area: A New Super-Ensemble-Based Probabilistic Projection. Agricultural and Forest Meteorology, 149, 1266-1278. https://doi.org/10.1016/j.agrformet.2009.02.015

Tao, F. L., \& Zhang, Z. (2010). Adaptation of Maize Production to Climate Change in North China Plain: Quantify the Relative Contributions of Adaptation Options. European Journal of Agronomy, 33, 103-116. https://doi.org/10.1016/j.eja.2010.04.002

Tesfaye, K., Gbegbelegbe, S., Cairns, J. E., Shiferaw, B., Prasanna, B. M., Sonder, K., Robertson, R. et al. (2015). Maize Systems under Climate Change in Sub-Saharan Africa: Potential Impacts on Production and Food Security. International Journal of Climate Change Strategies and Management, 7, 247-271. https://doi.org/10.1108/IJCCSM-01-2014-0005 
Tesfaye, K., Kruseman, G., Cairns, J. E., Zaman-Allah, M., Wegary, D., Zaidi, P., Erenstein, O. et al. (2018). Potential Benefits of Drought and Heat Tolerance for Adapting Maize to Climate Change in Tropical Environments. Climate Risk Management, 19, 106-119. https://doi.org/10.1016/j.crm.2017.10.001

Tingem, M., Rivington, M., \& Colls, J. (2008). Climate Variability and Maize Production in Cameroon: Simulating the Effects of Extreme Dry and Wet Years. Singapore Journal of Tropical Geography, 29, 357-370. https://doi.org/10.1111/j.1467-9493.2008.00344.x

Wang, W., Dong, X., Lu, Y., Liu, X., Zhang, R., Li, M., Pu, X. et al. (2018). Soil Water Balance and Water Use Efficiency of Rain-Fed Maize under a Cool Temperate Climate as Modeled by the AquaCrop. Paper Presented at the MATEC Web of Conferences.

Waongo, M., Laux, P., \& Kunstmann, H. (2015). Adaptation to Climate Change: The Impacts of Optimized Planting Dates on Attainable Maize Yields under Rainfed Conditions in Burkina Faso. Agricultural and Forest Meteorology, 205, 23-39. https://doi.org/10.1016/j.agrformet.2015.02.006

Webber, H., Gaiser, T., \& Ewert, F. (2014). What Role Can Crop Models Play in Supporting Climate Change Adaptation Decisions to Enhance Food Security in Sub-Saharan Africa? Agricultural Systems, 127, 161-177.

https://doi.org/10.1016/j.agsy.2013.12.006

White, J. W., Hoogenboom, G., Kimball, B. A., \& Wall, G. W. (2011). Methodologies for Simulating Impacts of Climate Change on Crop Production. Field Crops Research, 124, 357-368. https://doi.org/10.1016/j.fcr.2011.07.001

Whitfield, S. (2013). Uncertainty, Ignorance and Ambiguity in Crop Modelling for African Agricultural Adaptation. Climatic Change, 120, 325-340. https://doi.org/10.1007/s10584-013-0795-3

Xiao, D., \& Tao, F. (2016). Contributions of Cultivar Shift, Management Practice and Climate Change to Maize Yield in North China Plain in 1981-2009. International Journal of Biometeorology, 60, 1111-1122. https://doi.org/10.1007/s00484-015-1104-9

Xiao, D. P., Qi, Y. Q., Shen, Y. J., Tao, F. L., Moiwo, J. P., Liu, J. F., Liu, F. S. et al. (2016). Impact of Warming Climate and Cultivar Change on Maize Phenology in the Last Three Decades in North China Plain. Theoretical and Applied Climatology, 124, 653-661. https://doi.org/10.1007/s00704-015-1450-x

Xiong, W., Skalský, R., Porter, C. H., Balkovič, J., Jones, J. W., \& Yang, D. (2016). Calibration-Induced Uncertainty of the EPIC Model to Estimate Climate Change Impact on Global Maize Yield. Journal of Advances in Modeling Earth Systems, 8, 1358-1375. https://doi.org/10.1002/2016MS000625

$\mathrm{Xu}, \mathrm{H}$., Twine, T. E., \& Girvetz, E. (2016). Climate Change and Maize Yield in Iowa. PLoS ONE, 11, e0156083. https://doi.org/10.1371/journal.pone.0156083

Xu, X., Wang, L., Sun, D., Liu, L., \& Banson, K. E. (2017). The Impact of Climate Change on Yield Potential of Maize across China. International Journal of Plant Production, 11, 47-63.

Yang, X. L., Gao, W. S., Shi, Q. H., Chen, F., \& Chu, Q. Q. (2013). Impact of Climate Change on the Water Requirement of Summer Maize in the Huang-Huai-Hai Farming Region. Agricultural Water Management, 124, 20-27. https://doi.org/10.1016/j.agwat.2013.03.017

Zhang, Y., Zhao, Y., \& Feng, L. (2018). Higher Contributions of Uncertainty from Global Climate Models than Crop Models in Maize-Yield Simulations under Climate Change. Meteorological Applications, 26, 74-82. https://doi.org/10.1002/met.1738

Zinyengere, N., Mhizha, T., Mashonjowa, E., Chipindu, B., Geerts, S., \& Raes, D. (2011). 
Using Seasonal Climate Forecasts to Improve Maize Production Decision Support in Zimbabwe. Agricultural and Forest Meteorology, 151, 1792-1799.

https://doi.org/10.1016/j.agrformet.2011.07.015

Zydelis, R., Weihermuller, L., Herbst, M., Klosterhalfen, A., \& Lazauskas, S. (2018). A Model Study on the Effect of Water and Cold Stress on Maize Development under Nemoral Climate. Agricultural and Forest Meteorology, 263, 169-179.

https://doi.org/10.1016/j.agrformet.2018.08.011 